\title{
Kadar Glukosa Darah Tikus Putih (Rattus norvegicus L.) pada Periode Laktasi Setelah Pemberian Suplemen Telur Puyuh Organik
}

\section{Blood Glucose Levels of Rats (Rattus norvegicus $\mathbf{L}$.) in the Lactation Period After Supplemented with Organic Quail Eggs}

\author{
Citra Riandika ${ }^{1 *}$, Tyas Rini Saraswati*2, Sri Isdadiyanto*2 \\ ${ }^{1}$ Mahasiswa Program Studi Biologi, Departemen Biologi, Fakultas Sains dan Matemtika, \\ Universitas Diponegoro \\ ${ }^{2}$ Departemen Biologi, Fakultas Sains dan Matematika, Universitas Diponegoro \\ Email : citrariandika@gmail.com
}

Diterima 25 Juli 2019/ Disetujui 23 Agustus 2019

\begin{abstract}
ABSTRAK
Periode kebuntingan pada hewan membutuhkan nutrisi yang banyak sebagai akibat dari pemenuhan gizi indukan dan embrio. Penelitian ini dilakukan untuk menganalisis pengaruh suplementasi telur puyuh organik terhadap kadar glukosa darah Rattus norvegicus L saat laktasi. Penelitian ini menggunakan 20 ekor Rattus norvegicus L betina terdiri atas 5 perlakuan dengan 4 kali ulangan. Perlakuan pada penelitian ini terdiri atas T0: Rattus norvegicus L kontrol; T1: Rattus norvegicus L diberi suplemen telur yang diproduksi puyuh yang diberi pakan komersial; T2: Rattus norvegicus L diberi suplemen telur yang diproduksi puyuh yang diberi pakan organik standar; T3: Rattus norvegicus L diberi suplemen telur yang diproduksi puyuh yang diberi pakan organik yang mengandung daun singkong, ikan kembung dan kunyit, dan T4: Rattus norvegicus L diberi suplemen telur yang diproduksi puyuh yang diberi pakan organic yang mengandung daun singkong, rumput laut, dan kunyit. Penelitian ini menggunakan Rancangan Acak Lengkap (RAL). Data yang diperoleh dianalisis menggunakan Analysis of Variance (Anova) pada taraf signifikansi 5\%. Hasil analisis menunjukkan bahwa suplementasi telur puyuh organik yang tidak memberikan pengaruh $(\mathrm{P}<0.05)$ terhadap kadar glukosa darah. Penelitian ini dapat disimpulkan bahwa kadar glukosa darah tikus putih pada periode laktasi setelah pemberian suplemen telur puyuh organik berada pada taraf normal sehingga suplemen telur puyuh organik baik dikonsumsi pada periode laktasi.
\end{abstract}

Kata kunci : laktasi, telur, glukosa

\begin{abstract}
Pregnancy period in animals requires a lot of nutrition as a result of fulfilling the nutrition of broodstock and embryos. This study was conducted to analyze the effect of supplementation of organic quail eggs on blood glucose levels in lactation test animals. The study used 20 females wistar rats consisted of 5 treatments with 4 replications. The treatment of this study consisted of T0: control group; T1: rat suplemented with comercial quail eggs; T2: rat supplemented with standard organic quail eggs; T3: rat supplemented with organic quail eggs contained cassava leaves, mackerel and turmeric powder, and T4: rat supplemented with organic quail eggs contained cassava leaves, seaweed and turmeric powder. This research used a Completely Randomized Design. The obtained data were analyzed using Analysis of Variance (Anova) at 5\% significance level. This research concluded that the blood glucose levels of rats in the lactation period after suplementation of organik quail eggs were at normal level so organic quail eggs supplement were recommended in the lactation period.
\end{abstract}

Keywords : lactation, eggs, glucose

\section{PENDAHULUAN}

Periode laktasi membutuhkan gizi yang tinggi untuk memenuhi kebutuhan nutrisi, karena dibutuhkan oleh induk dan juga anaknya. Nutrisi digunakan sebagai sumber energi untuk induk, dan untuk anak. Nutrisi digunakan sebagai sumber pertumbuhan dan perkembangan jaringan maupun 
organ. Kebutuhan energi periode laktasi 6 bulan pertama sebesar 500/hari untuk menghasilkan jumlah susu normal. Total kebutuhan energi tikus selama menyusui akan meningkat menjadi 2400 kkal, karbohidrat $65 \mathrm{~g}$ / hari, protein $17 \mathrm{~g} /$ hari, dan lemak $20 \mathrm{~g}$ /hari yang akan digunakan untuk memproduksi air susu (Kurniasih dkk., 2010).

Asupan gizi harus seimbang karena pada periode laktasi rentan terhadap kekurangan gizi dan bisa menyebabkan gangguan metabolisme. Gangguan metabolisme dapat disebabkan akibat kekurangan kalori. Hal ini menyebabkan tubuh tidak dapat mempertahankan periode laktasi. Ketidakseimbangan asupan lemak juga dapat menyebabkan obesitas sehingga terjadi resistensi insulin. Kurangnya konsumsi serat kurang dari 25 g/hari dapat meningkatkan tingginya kadar glukosa di dalam darah (Dita dkk., 2013).

Glukosa darah berfungsi sebagai sumber energi utama. Menurut Murray et al.(2012) glukosa merupakan prekursor untuk pembuatan air susu. Tubuh induk dalam periode laktasi memiliki kadar glukosa darah normal $95-166 \mathrm{mg} / \mathrm{dL}$ (Goud et al., 2015). Kadar glukosa darah yang terlalu rendah dapat menyebabkan gangguan metabolisme. Kekerungan nutrisi ini sering disebabkan akibat dari pakan yang diberikan tidak memiliki kecukupan nurtisi yang dibutuhkan.

Salah satu alternatif untuk meningkatkan kandungan nutrisi telur puyuh adalah mengganti pakan standar dengan pakan organik. Telur puyuh organik merupakan telur yang dihasilkan dari puyuh yang diberi pakan organik. Pakan organik standar dengan penambahan serbuk kunyit, ikan kembung dan tepung daun singkong. Kandungan nutrisi protein telur puyuh organik $17,81 \mathrm{mg} / 100 \mathrm{~g}$, kolesterol 783,62 mg/100g, HDL 127, $39 \mathrm{mg} / 100 \mathrm{~g}$, LDL 133,5 mg/100mg ( Saraswati dkk., 2016 ). Telur organik juga mengandung asam lemak palmitat dan stearat yang tinggi dan sangat baik untuk dikonsumsi (Samman et al., 2009). Kandungan kolesterol dalam terlur organik dapat meningkatkan kadar glukosa dalam tubuh bila dikonsumsi.

Periode laktasi sendiri membutuhkan nutrisi yang seimbang. Salah satu gizi yang dibutuhkan adalah karbohidrat. Telur puyuh organik merupakan suplemen yang memiliki kandungan gizi yang kompleks dan juga memiliki kemampuan untuk mempertahankan kadar glukosa tetap seimbang, sehingga tepat digunakan sebagai suplemen pada periode laktasi (Pardede, 2007). Berdasarkan uraian di atas, perlunya dilakukan penelitian lebih lanjut tentang kadar glukosa darah tikus putih (Rattus noevegicus L.) yang diberi suplemen telur puyuh organik pada periode laktasi

\section{METODE PENELITIAN}

Penelitian dilakukan selama 6 bulan di Laboratorium Biologi Struktur dan Fungsi Hewan, Departemen Biologi Universitas Diponegoro. Tikus putih diperoleh dari peternak di Bukit Ngaliyan Permai, Semarang. Pelaksanaan uji kadar glukosa darah di Laboratorium Medik Analisis Kesehatan Fakultas Ilmu Keperawatan, Universitas Muhammadiyah Semarang. Bahan yang diperlukan dalam penelitian ini adalah telur puyuh komersil dan telur puyuh organik dan hewan uji berupa 25 ekor tikus putih betina dan 5 ekor tikus putih jantan. Bahan uji berupa akuades, kloroform, reagen glukosa untuk analisis glukosa darah. Pengamatan dilakukan saat Rattus norvegicus L dalam kondisi laktasi. Parameter penelitian ini adalah kadar glukosa darah, bobot badan tikus betina, konsumsi pakan dan minum.

Tiga puluh ekor tikus putih betina setelah diaklimasi dikawinkan dengan tikus putih jantan, dalam satu kandang ditempatkan 3 tikus betina dan 1 jantan selama 5 hari dalam durasi estrus 4-5 hari (Prawitasari, 2018). Deteksi kebuntingan pada tikus betina dilakukan dengan cara smear vagina, kemudian tikus yang bunting ditempatkan secara acak dengan model undian untuk menentukan nomor urut dan penempatan pada kandang individual berukuran $37 \mathrm{~cm} \times 30 \mathrm{~cm} \times 12 \mathrm{~cm}$. Pemberian perlakuan pakan yaitu pakan standar 50 gram dan satu butir telur puyuh organik tiap perlakuan per kandang uji, pada sore hari (pukul 15.00 - $17.00 \mathrm{WIB}$ ) selama 30 hari berturut - turut.

Pengambilan dilakukan dengan membedah tikus dari abdomen bawah sampai ke tulang rusuk menggunakan gunting bedah. Setelah dibedah, darah diambil menggunakan jarum suntik $3 \mathrm{ml}$, kemudian kedalam tabung. Pengambilan sampel serum menggunakan pipet kemudian disentrifugasi 
dengan kecepatan 10.000 selama 10 menit. Kadar glukosa darah diukur dengan spektrofotometer UVVis pada panjang gelombang $540 \mathrm{~nm}$. Cara penghitngan kadar glukosa darah menurut Kustiningsih dkk. (2007) sebagai berikut :

$$
=\frac{\text { As sampel }}{\text { Ast Standar }} \times \text { Kosnsentrasi standar }
$$

Keterangan : As = absorbansi sampel, Ast = absorbansi standar

\section{HASIL DAN PEMBAHASAN}

Hasil analisis dengan Anova pengaruh pemberian suplementasi telur puyuh organik terhadap kadar glukosa darah tikus putih periode laktasi menunjukkan hasil yang tidak berbeda nyata $(\mathrm{P}>0,05)$. Hal ini menunjukkan pemberian suplemen telur puyuh organik tidak berpengaruh terhadap kadar glukosa darah (Tabel 1.1). Hasil penelitian menunjukkan bahwa kadar glukosa darah T0, T1, T2, T3 dan T4 dalam keadaan normal, menurut Goud et al.(2015) bahwa kadar glukosa darah normal 95-166 ml/dL. Perlakuan T1 dan T2 menunjukkan bahwa gizi yang terkandung dalam telur tersebut sama tinggi dengan telur puyuh standar, telur puyuh pada perlakuan T1 mengandung karbohidrat $0,87 \%$; protein $12,63 \%$ dan lemak 11,12\%; perlakuan T2 mengandung protein $12,67 \%$; lemak $11,26 \%$; dan karbohidrat 0,91\% (Basri et al., 2018), sedangkan telur puyuh standar mengandung karbohidrat $1 \%$; lemak 11,1; dan protein 13,1. Kandungan telur puyuh pada perlakuan T1 dan T2 yang lebih tinggi dari telur puyuh standar dapat mengakibatkan kadar glukosa darah tinggi, tetapi hasil penelitian menunjukkan bahwa kadar glukosa darah tetap normal. Telur puyuh organik pada perlakuan T3 mengandung protein $13,02 \%$; lemak $11,31 \%$; dan karbohidrat 0,88\% (Basri et al., 2018).

Tabel 1. Hasil analisis rata-rata kadar glukosa darah $(\mathrm{mg} / \mathrm{dL})$, konsumsi pakan (g/hari), konsumsi minum (g/hari) dan bobot badan ( $\mathrm{g}$ ) tikus putih periode laktasi setelah pemberian suplemen telur puyuh organik

\begin{tabular}{|c|c|c|c|c|}
\hline Perlakuan & $\begin{array}{c}\text { Kadar Glukosa } \\
\text { Darah }(\mathbf{m g} / \mathbf{d L}) \\
-\mathbf{X} \pm \mathbf{S D}\end{array}$ & $\begin{array}{c}\begin{array}{c}\text { Konsumsi Pakan } \\
\text { (g/hari) } \\
-\mathbf{X} \pm \text { SD }\end{array}\end{array}$ & $\begin{array}{c}\text { Konsumsi } \\
\text { Minum (g/hari) } \\
{ }^{\mathbf{X}} \pm \text { SD }\end{array}$ & $\begin{array}{c}\text { Bobot Badan } \\
\text { Induk (g) } \\
\text { X } \pm \text { SD }\end{array}$ \\
\hline T0 & $112,75 \pm 6,18^{a}$ & $2,09 \pm 0,34^{\mathrm{a}}$ & $27,95 \pm 6,61^{\mathrm{a}}$ & $195,00 \pm 20,82^{a}$ \\
\hline T1 & $155,25 \pm 43,81^{\mathrm{a}}$ & $1,76 \pm 0,126^{\mathrm{a}}$ & $23,43 \pm 3,15^{\mathrm{a}}$ & $202,50 \pm 22,17^{a}$ \\
\hline $\mathbf{T 2}$ & $152,75 \pm 19,05^{\mathrm{a}}$ & $2,30 \pm 0,101^{\text {a }}$ & $31,26 \pm 3,27^{\mathrm{a}}$ & $195,00 \pm 12,91^{\mathrm{a}}$ \\
\hline T3 & $124,25 \pm 44,71^{\mathrm{a}}$ & $2,20 \pm 0,13^{\mathrm{a}}$ & $30,08 \pm 2,59^{\mathrm{a}}$ & $182,50 \pm 12,58^{\mathrm{a}}$ \\
\hline T4 & $119,50 \pm 22,48^{a}$ & $1,97 \pm 0,41^{\mathrm{a}}$ & $30,29 \pm 5,39^{\mathrm{a}}$ & $180,00 \pm 24,49^{a}$ \\
\hline
\end{tabular}

Keterangan : Angka dengan superskrip yang sama pada kolom yang sama menunjukkan tidak berbeda nyata $(\mathrm{P}>0,05) . \mathrm{T} 0=$ Kontrol; $\mathrm{T} 1$ : suplementasi telur puyuh pakan komersil; T2: suplementasi telur puyuh pakan organik standar; T3: suplementasi telur puyuh pakan organik standar, ikan kembung, kunyit, dan tepung daun singkong; T4: suplementasi telur puyuh pakan organik standar, rumput laut, kunyit, dan tepung daun singkong.

Perbedaan kandungan gizi telur puyuh organik pada perlakuan T1, T2, T3, T4 yang lebih tinggi dari T0 dapat mengakibatkan kadar glukosa darah tinggi tetapi energi yang digunakan induk untuk menyusui juga tinggi. Menurut Pardede (2007) Akibat proses laktasi adalah kenutuhan energi yang tinggi bagi induk. Hasil penelitian (Tabel 1.1) menunjukkan bahwa suplementasi telur puyuh organik dapat memenuhi kebutuhan gizi pada periode laktasi serta kadar glukosa darah pada taraf normal yaitu 112-155 mg/dL. Suhendra dkk., (2015) menyatakan bahwa energi yang berlebih didalam tubuh akan disimpan dalam bentuk glikogen, kemudian disimpan di dalam hati sehingga dapat digunakan sebagai bahan baku pembentukan laktosa susu.

Laktosa merupakan karbohidrat utama dalam air susu. Fungsi utama laktosa adalah mempertinggi 
absorbsi kalsium dan sumber energi. Air susu mengandung $7 \% \mathrm{~g}$ laktosa, laktosa dapat dihidrolisis menjadi glukosa dan galaktosa, fungsi galaktosa adalah nutrisi utama otak dan jaringan saraf (Ronaldoe, 2008). Yusuf (2014) menyatakan bahwa laktosa susu tidak hanya didapat dari proses sintesis asam propionat, laktosa juga dapat diperoleh dari proses glukoneogenesis dengan cara pembongkaran protein ketika energi ransum yang berupa karbohidrat dan lemak tidak mencukupi.

Rata-rata kadar glukosa darah Rattus norvegicus L yang diberi suplemen telur puyuh standar (T1), suplemen telur puyuh organik standar (T2), suplemen telur puyuh organik (T3) dan T4 tidak berpengaruh terhadap kadar glukosa darah. Hal ini menunjukkan bahwa pemberian suplemen telur puyuh tidak memberikan pengaruh nyata terhadap glukosa darah. Kadar glukosa darah hasil penelitian ini membuktikan adanya proses homeostasis yang mempertahankan kadar glukosa darah agar tetap dalam kondisi normal. Homeostasis terjadi pada saat glukosa memasuki hati. Glukosa diserap oleh usus halus dan hati, sedangkan glukosa yang berlebih akan dikonversikan menjadi glikogen dan disimpan di dalam hati $(<4 \%)$ dan otot $(<1 \%)$, sementara 30 sampai $40 \%$ dibongkar menjadi molekul-molekul trikarbon (trigliserida) dan disimpan sebagai lemak (Ganong, 2012).

Hasil analisis efek suplementasi telur puyuh organik pada kadar glukosa darah Rattus norvegicus $\mathrm{L}$ menunjukkan hasil yang tidak berbeda ( $p>0.05)$, hal tersebut disebabkan oleh nutrisi yang terkandung dalam suplemen telur puyuh organik seperti karbohidrat, protein dan lemak yang dapat mempengaruhi metabolisme tubuh dalam mensintesis glukosa. Karbohidrat yang dikonsumsi mempengaruhi kadar gula darah dan sekresi insulin. Menurut Fitri dan Yekti (2012) bahwa mekanisme hubungan asupan karbohidrat dengan kadar glukosa darah adalah karbohidrat akan dipecah dan diserap dalam bentuk glukosa. Penyerapan glukosa menyebabkan peningkatan sekresi insulin. Asupan karbohidrat yang terkandung dalam suplemen telur puyuh organik pada penelitian ini yang relatif sama menyebabkan efek suplementasi mampu mempertahankan kadar glukosa darah Rattus norvegicus L pada periode laktasi.

Peredaran zat-zat gizi dari karbohidrat, lemak, dan protein dalam proses metabolisme tersebut dipengaruhi oleh berbagai hormon, termasuk hormon insulin, glukagon, ephineprin, kortisol, dan hormon pertumbuhan. Hormon yang berpengaruh dalam mengatur kadar glukosa darah adalah insulin dan glukagon. Keadaan normal, produksi insulin oleh sel beta pangkreas meningkat sebanding dengan meningkatnya kadar glukosa dalam darah, hormon glukagon akan banyak diproduksi pada saat kadar glukosa dalam darah rendah. Regulasi dari produksi hormon insulin dan glukagon akan menjaga kadar glukosa darah dalam keadaan normal (James, 2010).

Berdasarkan hasil penelitian (Tabel 1.1) bahwa pada T1, T2, T3 dan T4 kadar glukosa darah tikus putih periode laktasi normal dibanding kontrol adalah adanya perubahan metabolisme (Hussein, 2013). Perubahan metabolisme ditandai dengan adanya peningkatan kebutuhan nutrisi induk tikus putih untuk pertumbuhan anaknya (Zhu et al., 2015). Peningkatan kebutuhan nutrisi dapat terpenuhi dari kandungan telur puyuh organik berupa asam lemak, karbohidrat, protein, vitamin, $\beta$-karoten, vitamin B12 dan antioksidan (Saraswati and Tana, 2016) yang kemudian akan melewati proses metabolisme didalam hepar untuk menghasilkan energi dan nutrisi bagi induk dan anak.

Hasil analisis dengan Anova pengaruh pemberian suplemen telur puyuh organik terhadap konsumsi pakan pada tikus putih periode laktasi menunjukkan hasil yang tidak berbeda nyata $(\mathrm{P}>0.05)$, hal tersebut juga menunjukkan bahwa konsumsi pakan tidak menyebabkan kadar glukosa darah tinggi atau tidak memberikan pengaruh yang nyata terhadap kadar glukosa darah induk Rattus norvegicus L (Tabel 1.1).

Asupan nutrisi yang tinggi pada periode laktasi, digunakan sebagai energi untuk aktivitas fisik induk. Asupan nutrisi akan diserap dan diedarkan melalui aliran darah dalam bentuk glukosa. Menurut Murray et al. (2012) bahwa konsumsi karbohidrat yang berlebih akan diserap ke dalam bentuk monosakarida glukosa. 
Rui (2014) menyatakan bahwa karbohidrat dicerna dan di proses oleh berbagai enzim glukosidase di saluran pencernaan menghasilkan glukosa. Glukosa masuk ke hepar melalui transportasi dari vena porta ke hepar. Glukosa dalam proses glikolisis menghasilkan piruvat yang kemudian akan dioksidasi menjadi ATP melalui siklus Krebs dan fosforilasi oksidatif. Glukosa dengan bantuan glikogen sintase digunakan sebagai prekursor untuk mensintesis glikogen sebagai cadangan energi.

Asam lemak yang diserap oleh saluran penernaan masuk kedalam hepar melalui pembuluh lakteal, kemudian terjadi proses esterifikasi oleh gliserol 3-fosfat untuk menghasilkan triasilgliserol (TAG) atau diesterifikasi dengan kolesterol untuk menghasilkan ester kolesterol. TAG dan ester kolesterol disimpan dalam bentuk tetes lemak di dalam hepar atau di sekresikan ke peredaran darah sebagai partikel Very Low-Density Lipoprotein (VLDL) (Rui 2014).

Protein secara parsial dipecah menjadi fragmen peptida oleh enzim pepsin dilambung, kemudian dipecah secara sempurna di dalam usus halus oleh enzim tripsin dan kimotripsin. Fragmen peptida didigesti oleh karboksipeptidase dan aminopeptidase menjadi asam amino bebas. Asam amino bebas atau peptida kecil masuk ke dalam kapiler darah pada vili kemudian dibawa ke hepar. Asam amino di dalam sitosol hepar mengalami proses transaminase untuk menghasikan energi (Chotechuang, 2011).

Faktor yang mempengaruhi konsumsi pakan adalah kadar glukosa darah, palatabilitas dan kebutuhan energi. Kadar glukosa darah dipengaruhi oleh beberapa faktor, seperti periode laktasi, asupan nutrisi dan aktivitas fisik. Periode laktasi mebutuhkan glukosa yang lebih banyak karena digunakan sebagai bahan pembentuk laktosa air susu. Hal tersebut sesuai dengan hasil penelitian bahwa konsumsi pakan yang diberikan pada perlakuan T0, T1, T2, T3, dan T4 tidak menaikkan kadar glukosa darah induk (Tabel 1.1). Yusuf (2014) menyatakan bahwa laktosa air susu juga diperoleh melalui proses glukoneogenesis dan digunakan sebagai makanan untuk anaknya.

Kronenberg et al. (2008) menyatkan bahwa kadar glukosa darah dipengaruhi oleh aktivitas fisik, ketika aktivitas tubuh tinggi penggunaan glukosa oleh otot akan ikut meningkat. Hasil penelitian ini menunjukkan bahwa kadar glukosa darah masih berada pada taraf normal sehingga konsumsi pakan dapat memenuhi kebutuhan saat periode laktasi.

Hasil penelitian ini juga menunjukkan bahwa rasa, bau dan penampilan telur tidak mempengaruhi palabititas. Asupan pakan rata - rata pada periode laktasi adalah 19,14-21,87 g/hari, sesuai dengan asupan pakan pada periode laktasi (Hubrecht and kirkwood, 2010). Periode laktasi kebutuhan energi semakin meningkat seiring dengan banyaknya jumlah anak yang dihasilkan, namun pada penelitian ini kebutuhan energi tercukupi dengan suplemen telur puyuh organik yang diberikan sehingga kebutuhan energi tidak mempengaruhi konsumsi pakan.

Hasil analisis dengan Anova pengaruh pemberian suplementasi telur puyuh organik terhadap konsumsi minum tikus putih periode laktsi menunjukkan hasil yang tidak berbeda nyata $(\mathrm{P}>0,05)$. Faktor yang mempengaruhi konsumsi minum antara lain faktor lingkungan dan osmolaritas cairan. Penelitian Purba et al. (2018) bahwa suplementasi telur burung puyuh organik juga tidak berpengaruh signifikan terhadap konsumsi minum selama periode laktasi ( $\mathrm{p}>0.05$ ), hal tersebut dikarenakan konsumsi minum dipengaruhi oleh suhu dan kelembaban . Suhu dan kelembaban selama masa penelitian adalah $26,40^{\circ}$ $\mathrm{C} \pm 26,69^{\circ} \mathrm{C}$ dan $76,89 \% \pm 78,55 \%$, masingmasing yang merupakan kondisi lingkungan yang optimal.

Kelembaban dalam kandang tikus tinggi, maka tikus akan mengalamai evaporasi dengan cara berkeringat yang disebabkan panas menumpuk didalam tubuh (Pardede, 2007). Kehilangan air dalam tubuh ini perlu diganti dengan air minum. Air berfungsi sebagai pengatur suhu tubuh karena menyerap panas yang dihasilkan dari metabolisme tubuh. Panas dalam tubuh dapat dikeluarkan dengan beberapa cara seperti mengeluarkannya lewat saluran pencernaan dan kulit, untuk mengatasi hal tersebut makan tikus pada periode laktasi harus minum air sedang atau sesuai kebutuhan periode laktasi (Purba et al., 2018). Berdasarkan hal 
tersebut faktor lingkungan tidak mempengaruhi konsumsi minum.

Faktor lain yang mempengaruhi konsumsi minum adalah osmolaritas cairan. Ketika terjadi peningkatan osmolaritas cairan ekstrasel maka akan merangsang osmoreseptor di hipothalamus, rangsangan tersebut akan dihantarkan ke neuron hipothalamus yang menyintesis hormon $\mathrm{ADH}$ (anti diuretic hormone). Hormon ADH akan dikeluarkan oleh hipofisis posterior ke dalam darah dan akan berikatan dengan reseptornya di duktus koligen. Ikatan tersebut memicu terbentuknya aquaporin, pembentukan ini memungkinkan terjadinya reabsorbsi cairan ke vasa recta. Hal ini menyebabkan urin yang terbentuk di duktus koligen menjadi sedikit dan hiperosmotik (pekat) sehingga cairan di dalam tubuh tetap dapat dipetahankan (Silverthon, 2010). Berdasarkan penelitian ini bahwa faktor lingkungan tidak mempengaruhi konsumsi minum sehingga osmolaritas cairan ekstrasel juga tidak berpengaruh.

Hasil analisis dengan Anova pengaruh pemberian suplementasi telur puyuh organik terhadap bobot badan induk tikus putih periode laktasi menunjukkan hasil yang tidak berbeda nyata ( $P>0,05)$. Salah Satu faktor yang mempengaruhi bobot badan adalah faktor pertumbuhan. Selama periode laktasi induk membutuhkan energi lebih tinggi yang digunakan untuk pertumbuhan anak anaknya, namun gizi yang terkandung dalam suplemen telur puyuh organik juga tinggi sehingga asupan gizi yang dibutuhkan untuk pertumbuhan anak terpenuhi. Peningkatan berat badan terkait dengan konsumsi pakan dan konsumsi minum. Konsumsi pakan dan konsumsi minum pada penelitian ini terpenuhi dengan baik sehingga berat badan juga tidak berpengaruh. Penelitian Prawitasari dkk. (2018) menyatakan bahwa bobot badan induk juga dipengaruhi oleh aktivitas metabolisme sedangkan suplementasi telur puyuh organik tidak mempengaruhi bobot badan induk pada periode laktasi.

\section{KESIMPULAN}

Hasil penelitian tersebut dapat disimpulkan bahwa kadar glukosa darah tikus putih pada periode laktasi setelah pemberian suplemen telur puyuh organik berada pada taraf normal sehingga suplemen telur puyuh organik baik dikonsumsi pada periode laktasi.

\section{UCAPAN TERIMAKASIH}

Terimakasih kami ucapkan kepada Dr. Tyas Rini Saraswati, M.Kes yang telah mengikutsertakan penelitian yang didanai melalui dana Hibah kompetisi Kemenristekdikti tahun 2017.

\section{DAFTAR PUSTAKA}

Basri, H., Saraswati, T.R., and Isdadiyanto, S. 2018. Hematological Status of Rats (Rattus norvegicus L.) in the Lactation Period After Giving Supplements Organic Quail Eggs. International Journal of Biological Research 6(1): 1-4.

Chotehuang, N. 2011 The Role of Amino Acids in Liver Protein Metabolism Under a High Protein Diet: Identification of Amino Acids Signal and Associated Transduction Pathway. Thesis. Food and Nutrition. AgroParisTech. Paris.

Dita, L.D., Purwato, S.D., dan Kaligis, S. 2013. Gambaran Kadar Glukosa Darah Puasa Pada Mahasiswa Angkatan 2011 Fakultas Kedokteran Universitas Sam Ratulangi Dengan Indeks Massa tubuh 18,5-22,9 $\mathrm{Kg} / \mathrm{M} 2$. Jurnal e-Biomedik (eBM). Vol 1(2) : 991-996.

Fitri, R, dan Yekti, W. 2012. Asupan Energi, Karbohidrat, Serat, Beban Glikemik, Latihan Jasmani dan Kadar Gula Darah pada Pasien Diabetes Mellitus tipe 2. Jakarta. Media Medika Indonesia.

Ganong, W. F. 2012. Buku Ajar Fisiologi Kedokteran. Jakarta: EGC

Goud, B.J., Dwarakanath, V., and Swamy, B.K.C. 2015. Streptozotocin- A Diabetagonic Agent in Animal Models. International Journal of Pharmacy and Pharmaceutical Research, 3(1): 253-265.

Hubrecht, R. and Kirkwood J. 2010. The UFAW handbook of the care and management of 
laboratory and other research animals. Is-sue8. University Federation for Animal Welfare. pp.311.https://doi.org/10.1002/97814443187 $\underline{77}$.

Hussein, E. 2013. Biochemical and Histopathologichal Studies on the Liver of Rats Administrated with Different Concentrations of Aqueous Extrack of Glycyrrhiza glaborus. Global Veterinaria 10(5): 491-495.

James, N. 2010. The Important of Insulin and Glukagon; Diabetes an Hypoglicemia. Http://Endrokineweb.com. Diakses 24 November 2018 pukul 22.00.

Kurniasih, D,. Hilmansyah, H., Astuti, M.P. dan Imam, S. 2010. Sehat dan Bugar Berkat Gizi Seimbang. Jakarta : P.T Penelitian Sarana Bobo.

Kronenberg, H. M., Melmed, S., Polonsky, K. S., and Larsen, P. R. 2008. Type 2 Diabetes Mellitus. Williams Textbook of Endocrinology. 11th Ed. Philadelphia: Saunders.

Muray, R. K., Granner dan Rodwell. 2012. Biokimia. Harper . 27th ed. EGC : Jakarta

Pardede, M.R. 2007. Perkembangan dan Pertumbuhan Ambing Tikus (Rattus norvegicus) Pada Usia Kebuntingan 13, 17, dan 21 Hari Akibat Penyuntikan bST (bovine Somatotropin). Skripsi. Bogor : IPB

Purba, S.L, T.R. Saraswati, and S. Isdadiyanto. 2018. The effect of organic quail egg suplementation on the blood lipid profile of white mice (Rattus norvegicus L.) during the lactation period. Journal of Physics: Conference Series. 1025.

Prawitasari, S., Saraswati, T.R., dan Tana, S. 2018. Struktur Histologi Hepar Tikus Putih (Rattus norvegicus ) Periode Laktasi Setelah Pemberian Suplemen Telur Puyuh Organik. Skripsi. UNDIP.

Ronaldoe. 2008. Suplementation With Vitamin E and Lactosa. Journal of Nutrition. 127: 190196.
Rui, L. 2014. Energy Metabolism in the Liver. Compr Physiol. 4(1): 177-197.

Samman S, Kung FP, Carter LM, Foster MJ, Phuyal J.L, and Petocz P. 2009. Fatty acid composition of certified organic, conventional and omega-3 eggs. Food Chemistry. 116 (4) : 911-914.

Saraswati, T.R dan Tana, S. 2016. Formulasi Pakan Organik Dan Serbuk Kunyit Untuk Meningkatkan Kandungan Asam Lemak Esensial Pada Telur Puyuh. Buletin Anatomi dan Fisiologi volume 2.

Saraswati, T.R., S. Tana, dan S. Isdadiyanto. 2016. Pemberian Berbagai Jenis Pakan Organik Terhadap Kandungan $\beta$-Karoten dalam Telur Puyuh Jepang (Coturnix japonica). Prosiding Seminar Nasional from Basic Science to Comprehensive Education. Jurusan Biologi, Fakultas Sains dan Teknologi, UIN Alauddin. Makassar.

Silverthron DU. 2010. Human physiology an integrated approach. 5thed. San Fransisco: Pearson.

Suhendra, D., Suprayogi, T.H. dan Sudjatmogo. tampilan lemak dan solid non fat pada usus sapi perah akibat asupan neutral detergen fiber yang berbeda. Animal Agriculture Journal 3(3): 424-429.

Yusuf, R. 2014. Kecernaan protein ransum kambing Peranakan Ettawa akibat pembedaan level protein ransum.Bioma. 3 (1): 1-15.

Zhu, W., Y. Mu, J. Liu, and Z. Wang. 2015. Energy Requirements During Lactation in Female Apodemus chevrieri (Mammalia: Rodentia: Muridae) in the Hengduan Mountain Region. Italian Journal of Zoology 82(2): 165-171. 